Research Article

\title{
The different mental health patient quality of life during shackling, treatment, and post treatment
}

\author{
Arif Widodo $^{1^{*}}$ and Supratman ${ }^{1}$ \\ ${ }^{1}$ Department of Nursing - Health Science Faculty - Universitas Muhammadiyah Surakarta, \\ Central Java, Indonesia.
}

*Correspondence: arif.widodo@ums.ac.id. Telp: +628164272436.

Received May 05, 2020; Accepted May 28, 2020; Published May 28, 2020

\begin{abstract}
Background: Mental health is a well-being mental state associated with happiness, joy, satisfaction, achievement, optimism, and hope. Good mental health allows a harmonious and productive life as an integral part of one's quality of life by taking into account all aspects of human life. This study aims to assess the different quality of life among mental health disorder patients during shackling, treatment, and post-treatment in Sukoharjo Regency.
\end{abstract}

Methods: Quantitative descriptive was used in this study. Our population was all mental disorder patient in Sukoharjo District who has experienced with shackling and finished the treatment in the RSJD "dr Arif Zainudin," Surakarta during 2011-2015. We took total sampling and excluded patients who died, move to another place, and recover. Thirty out of thirty-four post-shackling patients in the Sukoharjo Regency participated in this study. A tested questionnaire was used to collect the data from the patient. The analysis was performed using univariate analysis - central tendency value analysis.

Results: We found differences in patients' quality of life during shackling, treatment, and posttreatment. The survivor had the highest quality of life in the post-treatment phase compared to the shackled and treatment period.

Conclusions: The quality of life of post-treatment patients is better compared during shackled and treatment.

Keywords: quality of life, post shackling patients, people with mental disorders

\section{INTRODUCTION}

The Indonesia Law Number 18 of 2014 concerning Mental Health, in Chapter 1, Article 1, states that mental health is a condition of an individual who can develop physically, mentally, spiritually, and socially. Accordingly, the individual realizes his ability, able to overcome the pressure, work productively, and contribute to the community (1).

Mental health is a state of happiness, joy, satisfaction with the achievement of its business; it is a prosperous condition when someone enables to realize his potential, has good coping to stressors, productive, and can make a positive contribution to society $(2,3)$. Furthermore, according to Johnson, mental health is an emotionally, psychologically, and socially healthy, as seen from satisfying interpersonal relationships, effective coping behaviors, positive selfconcepts, and emotional stability (4). 


\section{Epidemiology and Society Health Review $\mid \mathbf{E S H R}$}

World Health Organization (WHO) report in 2003 stated that there were 450 million people in the world who had mental disorders (5). Human Rights Watch reported, Indonesia, that has more than 250 million of citizen only has $600-800$ psychiatrists. It means that one psychiatrist should handles 300,000 to 400,000 mental disorder patients (6).

According to Indonesia basic health research/Riskesdas, the prevalence of schizophrenia/psychosis increased from $0.17 \%$ to $0.18 \%(7,8)$. The incidence of schizophrenia/psychosis in Central Java in 2018 was $0.25 \%$ among $34,490,835$ citizens. This number implies $86,222,709$ psychotic patients must be treated (8). The capacity of psychiatric care services in Central Java is under 1,000 beds. This condition proves that psychiatric services can serve not all patients at the mental hospital in Central Java. The remaining untreated patients were in the community; they need close supervision by the health authority. Mental disorder patients, especially psychosis, will experience a reality orientation disorder, mood changes, personality disorder, habits, and or withdrawal that end up isolating themselves (9). The most psychotic patients are schizophrenic patients, who may initially be calm, but sometimes unexpectedly become aggressive without apparent psychosocial stressors. Accordingly, the family and community shackled survivors to avoid unexpected events such as hurt and disturbing themselves and surrounding people.

Factors that affect the quality of life of schizophrenic patients are essential to be studied to see the indicators of people's mental health. Factors which influence the quality of life of schizophrenic patients: 1) socio-demographic variables such as gender, marital status, education level, occupation, and income level, 2) clinical variables, for instance, psychopharmaceutical use, side effects of drugs consumption, delay in getting treatment, and agitation (10).

After shackling, survivors may recover from severe mental disorders, get back to the community for work, and live like ordinary people. However, the recovery process does not always run smoothly; sometimes, there are ups and downs. To reach the recovery process well, it needs support from various parties, especially from the survivor family or close friend, health workers, their fellow, and their surrounding communities.

Based on the above background, we are interested in examining the differences in the quality of life of patients being shackled, the time of care, and post-treatment of patients after shackling in the Sukoharjo Regency.

\section{METHODS}

This study aimed to assess the different quality of life of mental health disorder patients during their shackling, treatment in hospital, and post-treatment in Sukoharjo, Central Java of Indonesia. We designed this study using quantitative descriptive. A tested questionnaire was employed to collect information from the respondent. Questionnaire consist of 23 Likert scale items: always, frequently, sometimes, ever, never. The favorable questions were scored from 4 to 0 and vice versa for unfavorable questions. We involved all patients who recorded in mental health hospitals/RSJD "dr Arif Zainudin" of Surakarta and excluded patients: died, move to another place, and recover. The analysis was performed using univariate analysis by central tendency analysis.

\section{RESULTS}

Thirty out of thirty-four post-treatment patients in RSJD "dr Arif Zainudin" of Surakarta participated in this study. One patient died, two patients were moving to another place, and a patient has been recovering. Characteristic of the respondent was presented in Table 1. 


\section{Epidemiology and Society Health Review $\mid \boldsymbol{E S H \boldsymbol { R }}$}

Tabel 1. The Distribution of Respondent characteristic frequency

\begin{tabular}{lcc}
\hline Characteristic & $\begin{array}{c}\text { Frequency } \\
\mathbf{N}=\mathbf{3 0}\end{array}$ & $\%$ \\
\hline Sex & 14 & \\
$\quad$ Female & 16 & $47,7 \%$ \\
$\quad$ Male & & $53,3 \%$ \\
Education & 10 & \\
$\quad$ Elementary & 10 & $33,3 \%$ \\
$\quad$ Junior High School & 9 & $33,3 \%$ \\
$\quad$ Senior High School & 1 & $30,0 \%$ \\
$\quad$ Bachelor/Diploma & 2 & $3,4 \%$ \\
Time of being mental health disorder survivor & \\
$\quad<10$ years & 18 & $6,7 \%$ \\
$\quad 11-20$ years & 10 & $60,0 \%$ \\
$\quad>20$ years & 18 & $33,3 \%$ \\
Time of being shackled & 10 & $60,0 \%$ \\
$\quad<10$ years & 2 & $33,3 \%$ \\
$\quad 11-20$ years & $6,7 \%$ \\
$\quad$ > 20 years & 12 & \\
Time of being treated in mental disorder hospital & \\
$\quad<5$ months & 13 & $40,0 \%$ \\
$\quad 6-10$ months & 5 & $43,3 \%$ \\
$\quad>11$ months & $16,7 \%$ \\
\hline
\end{tabular}

The majority of the respondent (53.3\%) were male. Most of the respondents were graduated from elementary school. Sixty percent of respondents were mental health disorders for 11-20 years. More than half of the respondents were being shackled for less than ten years. Most of them were being treated in hospital for 6-10 months (Table 1).

The difference in the quality of life during shackling, treatment, and post-shackling can be seen in Table 2. During shackling, we found 37.90 of the mean. The shackling period experienced an increase in quality of life with a mean of 53.56. Subsequently, post-shackling experienced an increase in quality of life, marked with the mean 64.73 .

Table 2. Statistical Data on Quality of Life Scores when being shackled.

\begin{tabular}{lccccc}
\hline \multirow{2}{*}{ Quality of Life } & \multirow{2}{*}{ Mean } & \multirow{2}{*}{ Median } & \multicolumn{2}{c}{ Score } & \multirow{2}{*}{ SD } \\
\cline { 4 - 5 } & & & Minimum & Maximum & \\
\hline Being Shackled & 37.90 & 33.00 & 22.00 & 69.00 & 10.66 \\
\hline Treatment & 53.56 & 53.00 & 37.00 & 82.00 & 10.22 \\
\hline Post-treatment & 67.30 & 71.50 & 42.00 & 91.00 & 11.89 \\
\hline
\end{tabular}

Table 3 shows the different quality of life of the mental health disorder survivor. We found that the quality of life was different in the 3 different stages. In the shackled 


\section{Epidemiology and Society Health Review $\mid \boldsymbol{E S H \boldsymbol { R }}$}

period, the survivor had a low quality of life. It was different in the treatment period where the survivor in a moderate level of quality of life. Last, in the post-treatment, the survivor had a high or good quality of life.

Table 3. Frequency distribution of quality life

\begin{tabular}{llll}
\hline Quality of Life & $\begin{array}{c}\text { Being shackled } \\
\mathbf{N}(\%)\end{array}$ & $\begin{array}{c}\text { Treatment } \\
\mathbf{N ~ ( \% )}\end{array}$ & $\begin{array}{c}\text { Post-treatment } \\
\mathbf{N}(\%)\end{array}$ \\
\hline High & $2(6.7)$ & $5(16.7)$ & $15(25.0)$ \\
Moderate & $12(40.0)$ & $20(53.6)$ & $11(36.7)$ \\
Low & $16(53.3)$ & $5(16.7)$ & $4(13.3)$ \\
\hline Total & $30(100)$ & $30(100)$ & $30(100)$ \\
\hline
\end{tabular}

\section{DISCUSSIONS}

People with mental disorders who are depressed can get trauma, feel discarded, inferiority, despair, and hatred to their family (12). They also suffer from stigma and discrimination from other people that produce the worst situation for the survivor. Stigma, discrimination, and beatings by families most often experienced by people with mental illnesses (ODGJ). Shackling also occurs due to a lack of understanding of the community toward mental health (13).

Previous research said that shackling is considered a necessary step to protect patients and others from the aggressive behavior of patients (14). The lack of finances and dissatisfaction with mental health care services forced the family members to seek alternative treatment. Poor knowledge and misunderstanding about schizophrenia are common in family members and community leaders. Improving mental health services, especially in rural areas and emphasizing accessibility and quality, is very important. Health education about schizophrenia, common misconceptions, and timely administration and appropriate treatment are urgently needed.

The study results showed that the quality of life of patients during the treatment period was mostly moderate. This indicates that the quality of life of patients during the treatment has not entirely changed better compared to survivor in a shackled period. Shackling causes the patient not to be able to stand up, contracture, damage organs, ease for infectious diseases such as tuberculosis, death, separate from family, getting worst of mental disorders, slow healing, alienation, embarrassed, and violate human rights.

Appropriate care and support to people with mental disorders can individually recover from their illness and have a satisfying and productive life. Recovery is the process in which a person can live, work, study, and participate fully in his community. The results are shown with a mean of 53.56 of the patients' quality of life during the treatment period. Efforts to restore or rehabilitate people with mental disorders aim to prepare shackling patients in the community; therefore, a psychosocial rehabilitation program is needed. Psychosocial rehabilitation service programs for people with a post-shackling mental illness are required to restore individuals both of their rights and functions as independent citizens; and also can improve their social skills both in the family and community.

The study results showed that the quality of life of patients after treatment was mostly in the high/good category. This indicates that post-treatment patients have improved their quality of life. Problems that still happen after retention are in the form of stigma and discrimination. People with mental disorders often get stigma from the surrounding environment. The stigma is inherent in himself and his family. This is because people with mental illnesses are believed 


\section{Epidemiology and Society Health Review $\mid \boldsymbol{E S H R}$}

to be dangerous and unpredictable, less competent, unable to work, must be treated at the mental hospital, and will never get healthy (15). Mental disorders lead to a decrease in productivity, increase maintenance costs, and tend to cause problems, such as persecution and torture. Appropriate care and support to people with mental disorders on an individual basis can recover from illness and have a satisfying and productive life. Recovery is the process in which a person can live, work, study, and participate fully in his community. Return is the ability to live a good and productive life. Rehabilitation is a variety of activities in the form of physical activity, psychosocial adjustments, and vocational training to prepare them and obtain a maximum function and adjustment.

Quality of life is an individual's perception of his position in life, has to do with values and cultural systems related to ideals, hopes, and views, which are multidimensional measurements. They can not be measured only on physical effects and psychological treatment (16). It is explained that the factors related to a person's quality of life are age, sex, level of education, and employment (17).

Previous research shows that the misuse of human rights shackling cases does not represent the family or society's ignorance or refusal of psychiatric treatment. But it is linked to the neglect of the government and the responsibility to provide essential mental health services for people with mental illness (18). Systematic strategies need to be developed to eradicate this practice. This will require the collaborative participation of policymakers, service developers and managers and health professionals, development NGOs, bilateral institutions, and civil society organizations, including those who have a vivid focus on promoting and protecting the most vulnerable human rights in low-resource settings.

Finally, the only effective and sustainable strategy to eradicate this practice is to ensure the families and communities have affordable and equitable access to essential mental health services. Provision of basic community mental health services, where none existed before, allows the majority of people who have detained to receive psychiatric treatment and will be released from shackles.

This study shows that the majority of post-treatment psychiatric patients have an adequate quality of life. This condition is possibly caused by families' ability to care for and utilize health services to increase the quality of life of patients after treatment. Caring for a sick family member is a form of affection that occurs between family members. The study's results are supported by previous findings that families' ability to care for post-shackling patients dramatically influences the quality of life of shackling patients (19). It is supported by the ignorance of the community or family who has a family member suffers from a mental disorder toward the treatment. In simple terms, the community needs to be given an understanding of shackling; it is following all acts of binding and physical restraint that can result in the loss of one's freedom. From this point of view, deprivation includes neglect, is contrary to humanity, and violates human rights (human rights) and to sufferers of mental disorders (19).

This research shows the differences in quality of life during shackling, treatment, and postspackling. When on shackling, the mean was 42.06, the shackling period experienced an increase in quality of life with an average of 53.56. Subsequently, post-shackling experienced an increase in quality of life, namely the mean obtained 64.73 . This study shows that there are differences in the quality of life when shackling, treatment period, and post-treatment in the working area of Sukoharjo District Health Center. This is because post-shackling psychiatric patients are free from restraints and have received proper care, but this also does not rule out recurrence and retention. Proper family care for people with a mental health condition affects the success of the patient's treatment. The results of this study are supported by previous research that providing schizophrenia patient relaxation is very effective in 


\section{Epidemiology and Society Health Review $\mid \boldsymbol{E S H R}$}

reducing muscle tension, anxiety, and fatigue experienced by clients, which will affect the client's mental status (20).

The family is the main "nurse" and the biggest support system for clients. Mental disorders experienced by clients will cause a variety of responses from the family and the environment, one of them is in the form of shackling one by the family of people with a mental health condition when they are deemed dangerous for the environment. Shackling done by the family is strongly influenced by family behavior, including predisposing, enabling, and reinforcing factors. The concept of family is elaborated through several aspects, namely ability, function, role, task, and family characteristics. All of these factors affect the ability of families to take care of mental disorder patients.

The results of this study are supported by previous research, who stated that there is a relationship between relapses in schizophrenia patients (20). It shows that with a good attitude in the family can prevent the recurrence of schizophrenic patients. The family attitude of schizophrenia patients in this study attitude can be an effective or positive or negative assessment of an object, which is an effort to improve family attitudes in providing support or caring for schizophrenic patients. It is done by increasing their knowledge first because the level of knowledge will determine one's attitude and behavior. In this respect, someone can play a role in improving health at home and their behavior.

Former research explained that prevention of containment could be carried out with simultaneous efforts to strengthen basic mental health services and health education regarding schizophrenia or mental illness, common misunderstandings, and the importance of timely and appropriate care needed, especially in rural areas (21). Generally, family members and the community assume that shackling is required for safety reasons because of the patient's aggressive behavior, such as physical violence against neighbors, stealing food, and others. According to community leaders, families often do not respond to patient requests to be released from shackles. Family members have a lack of finance to seek mental health care and are also dissatisfied with the services. Health service providers have insufficient knowledge and prevailing misconceptions about schizophrenia in the community.

The form of care activities on the simple matter is possible to be carried out by the family; it gives a spontaneous feeling of care done by other family members. Furthermore, it can be concluded that the ability of the family to carry out the task of caring for sick family members will minimize the possibility of psychiatric patients who are being shackled. Shackling decreases the physical and social abilities of the patient in their life. Research shows that the impact of shackling decreases the ability to care for themselves, the cognitive abilities of patients, and the ability of patients to interact with social life. Mental illness is still carried out by families nowadays (22). The situation is contrary to the declaration of the Minister of Health of the Republic of Indonesia on October 10, 2010, namely Towards Indonesia Free Shackling. The reason is that it violates the law owned by the Indonesian state because mental disorders can be cured, and people with mental disorders are entitled to humanized treatment and treatment services. Thus, Indonesia Free Shackling has the meaning of efforts to make Indonesia free nationally from the practice of shackling and neglect of people with mental disorders. Another research concluded that psychosocial care for adolescents who live with parents with shackling patients should consider the psychological and social impacts as a result of caring for their parents with shackling (23).

Using family approaches, we can improve the quality of a person's life. Health promotion from the labor force health to family and patients, it is a form of family care with and health workers to improve the quality of life of patients with a fitted mental disorder (24). A study said that there was a strong relationship between saving and household economic status (25). According to Indonesia basic health research/Riskesdas, the most contributing factor to 


\section{Epidemiology and Society Health Review $\mid \mathbf{E S H R}$}

shackling in Indonesia is the household financial status (8). This factor is worsened by the lack of health care facilities and the distance from urban areas.

\section{CONCLUSIONS}

The quality of life of post-shackling patients in Sukoharjo regency when being installed has a low quality of life. There is a difference between the quality of life of patients when being shackled, the period of treatment, and post-treatment of shackling patients in the working area of Sukoharjo Health Center, namely the mean at shackling 37.90 , the period of treatment 53.56 and post-treatment 67.30 .

\section{Authors' Contribution}

All authors contributed equally to writing these articles.

\section{Funding}

This research was funded by LPPM Universitas Muhammadiyah Surakarta.

\section{Conflict of interest}

All authors declare that there is no conflict of interest.

\section{REFERENCES}

1. Ministry of Law and Human Rights/Kemenkumham. Undang-Undang Kesehatan Republik Indonesia, No. 18 Tahun 2014 Tentang Kesehatan Jiwa (2014). Tidak dipublikasikan tersimpan dalam lembaran negara RI Tahun 2014, Nomor 185.

2. Varcariolis EM, Carson VB, Shoemaker N. Foundation of Psychiatric Mental Health Nursing: A Clinical Approach. (5th ed.), St. Louis Saunders Elsevier; 2006.

3. Stuart GW and Laraia. Principles and Practice of Psychiatric Nursing. ( $8^{\text {th }}$ ed.), Missouri: Elsevier Mosby; 2005.

4. Videbeck SL. Psychiatric Mental Health Nursing. (3rd ed.), Philadelphia: Lippincott Williams \& Wilkins; 2006.

5. WHO. Mental Health. Geneva; 2003 [cited 2020 May 28]. Available from: www.who.int/mental_health

6. Human Rights Watch. Indonesia: Treating Mental Health with Shackles | Human Rights Watch. 2016 [cited 2020 May 28]. Available from: https://www.hrw.org/news/2016/03/20/indonesia-treating-mental-health-shackles

7. Indonesia Ministry of Health. Indonesia Basic Health Research (Riskesdas) 2013. Badan Penelitian dan Pengembangan Kesehatan (Balitbangkes) RI, Jakarta; 2014.

8. Indonesia Ministry of Health. Indonesia Basic Health Research (Riskesdas) 2018, Badan Penerbitan dan Pengembangan Kesehatan (Balitbangkes) RI, Jakarta; 2018.

9. Stuart GW. Prinsip dan Praktik Keperawatan Kesehatan Jiwa. (Bahasa Indonesia Ed.). Singapore: Elsevier Mosby; 2015.

10. Cardoso CS, Caiaffa WT, Bandeira M, Siqueira AL, Abreu MNS, Fonseca JOP. Factors associated with low quality of life in schizophrenia. ARTIGO. 2005;21(5):1338-40.

11. Risnawati D. Pamungkas IY \& Suwarni A. Hubungan Peran Serta Keluarga Pasien Gangguan Jiwa Dengan Perawatan Pasca Hospitalisasi Di Desa Gedangan Grogol Sukoharjo. Jurnal IImu Keperawatan Indonesia. 2014; 7(2):103-110

12. Lestari $W \&$ Wardani $Y Z$. Stigma dan Penanganan Penderita Gangguan Jiwa Berat yang Dipasung. Buletin Penelitian Sistem Kesehatan. 2015; 17(2):156-166

13. Fitriani. Prinsip Dasar dan Aplikasi Penulisan Laporan Pendahuluandan Strategi Pelaksanaan Tindakan Keperawatan. Jakarta: Salemba Medika; 2009. 


\section{Epidemiology and Society Health Review $\mid \boldsymbol{E S H \boldsymbol { R }}$}

14. Laila NH, Mahkota R, Krianto T, Shivalli S. Perceptions about pasung (physical restraint and confinement) of schizophrenia patients: A qualitative study among family members and other key stakeholders in Bogor Regency, West Java Province, Indonesia 2017. Int J Ment Health Syst. 2018; 12(1):1-7. Available from: https://doi.org/10.1186/s13033-018$\underline{0216-0}$

15. Lestari IP, Choiriyyah Z \& Mutgafi. Kecenderungan atau Sikap Keluarga Penderita Gangguan Jiwa Terhadap Tindakan Pasung (Studi Kasus di RSJ Amino Gandho Hutomo Semarang). Jurnal Keperawatan Jiwa. 2014; 2(1):14-23

16. Siregar AR and Muslimah RN. Gambaran Kualitas Hidup Pada Wanita Dewasa Awal Penderita Kanker Payudara. Psikologia: Jurnal pemikiran \& penelitian psikologi, 2018; 9(3):142-152.

17. Yusra A. Hubungan antara dukungan keluarga dengan kualitas hidup pasien diabetes mellitus tipe 2 di poliklinik penyakit dalam Rumah Sakit Umum Pusat Fatmawati Jakarta. Tesis. Universitas Indonesia; 2011. Available from: http://lib.ui.ac.id/file?file=digital/20280162-T Aini Yusra.pdf

18. Minas $\mathrm{H}$ and Diatri $\mathrm{H}$. Pasung: Physical restraint and confinement of the mentally ill in the community. International Journal of Mental HealthSystems. 2008; 2(1):1-5. DOI:10.1186/1752-4458-2-8.

19. Mugianti S and Suprajitno. Prediction of Mental Disorders Deprived by Family. J Ners. 2014;9(1):118-25.

20. Wulansih S and Widodo A. Hubungan Antara Tingkat Pengetahuan dan Sikap Keluarga Dengan Kekambuhan Pada Pasien Skizofrenia di RSJD Surakarta. Berita IImu Keperawatan. 2008; 1(4):181-186.

21. Harry M and Hervita D. Pasung: Physical Restraint and Confinement of the Mentally III in the Community. International Journal of Mental Health Systems. 2008; 2(8): DOI:10.1186/1752-4458-2-8. http://www.ijmhs.com/content/2/1/8

22. Suharto, B. Budaya Pasung dan Dampak Yuridis sosiologi (Studi Tentang Upaya Pelepasan Pasung dan Pencegahan Tindakan Pemasungan di Kabupaten Wonogiri). IJMS Indonesia Journal on Medical Science. 2014; 1(2): 1-10.

23. Buanasari A, Helena N, Daulima C, Wardani IY. Enfermería Clínica. Enferm Clin. 2018; 28:83-7.

24. Widodo A, Prabandari YS, Sudiyanto A, Rahmat I. Increasing the Quality of Life of Post Shackling Patients Through Multilevel Health Promotion of Shackling Prevention. Bali Med J. 2019; 8(2):678.

25. Idiaiani $S$ and Raflizar. Faktor yang Paling Dominan Terhadap Pemasungan Orang Dengan Gangguan Jiwa di Indonesia. Buletin Penelitian Sistem Kesehatan. 2015; 18(1):1-17. 